\title{
Crystal Structures of Two Macrocyclic Bischalcones Possessing 26-Membered Rings
}

\author{
Rina Mondal, Nayim Sepay, Debajyoti Ghoshal, and Asok K. Mallik \\ Department of Chemistry, Jadavpur University, Kolkata 700 032, India \\ Correspondence should be addressed to Asok K. Mallik; mallikak52@yahoo.co.in \\ Received 13 May 2015; Revised 11 July 2015; Accepted 13 July 2015 \\ Academic Editor: Paul R. Raithby \\ Copyright ( 2015 Rina Mondal et al. This is an open access article distributed under the Creative Commons Attribution License, \\ which permits unrestricted use, distribution, and reproduction in any medium, provided the original work is properly cited. \\ Single crystal X-ray diffraction of two macrocyclic bischalcones, namely, (2E,25E)-11,17,33,37-tetraoxapentacy- \\ clo[36.4.0. $0^{5,10} \cdot 0^{18,23} \cdot 0^{27,32}$ ]dotetraconta-1(42),2,5,7,9,18,20,22,25,27,29,31,38,40-tetradecaene-4,24-dione(1) and (2E,24E)-11,16,32,37- \\ tetraoxapentacyclo $\left[36 \cdot 4 \cdot 0 \cdot 0^{5,10} \cdot 0^{17,22} \cdot 0^{26,31}\right]$ dotetraconta-1(42),2,5,7,9,17,19,21,24,26,28,30,38,40-tetradecaene-4,23-dione(2), each \\ containing a 26-membered ring, has been studied. Compound 1 belongs to the monoclinic system, space group $C 2 / c$ with $a=$ \\ 34.3615(9) $\AA, b=12.7995(3) \AA, c=14.6231(3) \AA, \beta=96.912(2)^{\circ}, V=6,384.6(3) \AA^{3}$, and $Z=8$. Compound 2 is triclinic, space group \\ $P-1$ with $a=10.066(2) \AA, b=10.670(3) \AA, c=16.590(3) \AA, \alpha=85.95(2), \beta=89.244(14), \gamma=62.211(13), V=1572.0(6) \AA^{3}$, and $Z=2$. \\ Intermolecular $\mathrm{C}-\mathrm{H} \cdots \mathrm{O}$ hydrogen bonding interactions are present in both compounds.
}

\section{Introduction}

Compounds containing the chalcone (1,3-diphenyl-2propen-1-one) moiety [1] are known to possess important biological activities such as antimicrobial [2], antiviral [3], antibacterial [4,5], antihelminthic [5], antimalarial [6, 7], and antitumor [8] activities. Moreover, these compounds can be transformed in a number of ways into other biologically active heterocycles, for example, pyrimidines [9], isoxazole and pyrazole [10], and pyridines [11]. Macrocycles incorporating more than one chalcone moiety have great potential in generating new compounds suitable for molecular recognition [12-15] and photophysical $[16,17]$ studies. Recently, we reported the synthesis of a new family of 22- to 28 -membered macrocycles containing two chalcone moieties. For structural confirmation, an X-ray crystallographic study of one compound of this family has been done [18]. The interesting aspects of that study arising out of the folded nature of the molecule encouraged us to record the X-ray crystallographic data of some other compounds of the family. In this paper, we report the X-ray crystallographic data of two other compounds, (2E,25E)-11,17,33,37-tetraoxapentacyclo[36.4.0.0 $\left.0^{5,10} \cdot 0^{18,23} \cdot 0^{27,32}\right]$-dotetraconta-1(42),2,5,7,9,18,20,22, 25,27,29,31,38,40-tetradecaene-4,24-dione (1) and (2E,24E)$11,16,32,37$-tetraoxapentacyclo[36.4.0.0 $\left.0^{5,10} \cdot 0^{17,22} \cdot 0^{26,31}\right]$ dotetraconta-1(42),2,5,7,9,17,19,21,24,26,28,30,38,40-tetradecaene4,23-dione (2), each having a 26-membered ring.

\section{Experimental}

2.1. Synthesis of $\mathbf{1}$ and 2. Synthesis of the macrocyclic bischalcones (2E,25E)-11,17,33,37-tetraoxapentacyclo-[36.4.0.0 $\left.0^{5,10} \cdot 0^{18,23} \cdot 0^{27,32}\right]$ dotetraconta-1(42),2,5,7,9,18,20, $22,25,27,29,31,38,40$-tetradecaene-4,24-dione (1) and (2E, $24 E)$-11,16,32,37-tetraoxapentacyclo[36.4.0.0 $0^{5,10} \cdot 0^{17,22} \cdot 0^{26,31}$ ]dotetraconta-1(42), 2,5,7,9,17,19,21,24,26,28,30,38,40-tetradecaene-4,23-dione (2) (Scheme 1) was completed using the Claisen-Schmidt reaction in highly diluted aqueous methanol solution. The methods for the synthesis of $\mathbf{1}$ and 2 and their spectral data have been presented in our previous paper [18]. The light yellow single crystals of these compounds were obtained by slow evaporation of solvents from their solutions in $n$-hexane and acetone $(1: 3, \mathrm{v} / \mathrm{v})$ (melting points: $1,182-184^{\circ} \mathrm{C} ; 2,162-164^{\circ} \mathrm{C}$ ). 
TABLE 1: Crystallographic and experimental data for $\mathbf{1}$ and $\mathbf{2}$.

\begin{tabular}{|c|c|c|}
\hline Compounds & 1 & 2 \\
\hline Empirical formula & $\mathrm{C}_{38} \mathrm{H}_{36} \mathrm{O}_{6}$ & $\mathrm{C}_{38} \mathrm{H}_{36} \mathrm{O}_{6}$ \\
\hline Color/shape & Light yellow & Light yellow \\
\hline Formula weight & 588.67 & 588.67 \\
\hline Crystal system & Monoclinic & Triclinic \\
\hline \multirow[t]{2}{*}{ Space group } & $\mathrm{C} 2 / \mathrm{c}$ & $\mathrm{P}-1$ \\
\hline & $a=34.3615(9) \AA, \alpha=90$ & $a=10.066(2) \AA, \alpha=85.95(2)$ \\
\hline \multirow[t]{2}{*}{ Unit cell dimensions } & $b=12.7995(3) \AA, \beta=96.912(2)$ & $b=10.670(3) \AA, \beta=89.244(14)$ \\
\hline & $c=14.6231(3) \AA, \gamma=90$ & $c=16.590(3) \AA, \gamma=62.211(13)$ \\
\hline Volume & $6384.6(3) \AA^{3}$ & $1572.03(125) \AA^{3}$ \\
\hline$Z$ & 8 & 4 \\
\hline Density (calculated) & $1.225 \mathrm{~g} \mathrm{~cm}^{-3}$ & $1.24 \mathrm{~g} \mathrm{~cm}^{-3}$ \\
\hline Absorption coefficient & $0.082 \mathrm{~mm}^{-1}$ & $0.083 \mathrm{~mm}^{-1}$ \\
\hline$F(000)$ & 2496 & 624 \\
\hline Crystal size & $0.12 \times 0.09 \times 0.11 \mathrm{~mm}^{3}$ & $0.12 \times 0.09 \times 0.11 \mathrm{~mm}^{3}$ \\
\hline Theta range for data collection & $1.2-27.6$ & $2.2-27.7$ \\
\hline Limiting indices & $-44 \leq: h \leq 44,-16 \leq: k \leq 16,-18 \leq: l \leq 18$ & $-12 \leq: h \leq 12,-13 \leq: k \leq 13,-18 \leq: l \leq 20$ \\
\hline Reflections collected & 50677 & 20993 \\
\hline Independent reflections & $7,334[R($ int $)=0.038]$ & $5673[R($ int $)=0.093]$ \\
\hline Reflections observed $(I>2 \backslash \sigma(I))$ & 3677 & 1534 \\
\hline Refinement method & Full-matrix least-squares on $F^{2}$ & Full-matrix least-squares on $F^{2}$ \\
\hline Data/restraints/parameters & $7,334 / 1 / 413$ & $5673 / 1 / 413$ \\
\hline Goodness-of-fit on $F^{2}$ & 1.00 & 0.567 \\
\hline Final $R$ indices $[I>2 \sigma(I)]^{\mathrm{a}}$ & $R_{1}=0.047, w R_{2}{ }^{b}=0.105$ & $R_{1}=0.0657, w R_{2}=0.155$ \\
\hline$R$ indices (all data) & $R_{1}=0.114, w R_{2}=0.130$ & $R_{1}=0.242, w R_{2}=0.260$ \\
\hline Weighting scheme & $\left.w=1 /\left[\sigma^{2}\left(F_{0}^{2}\right)+0.0537 P\right)^{2}+0.8426 P\right]$ & $\left.w=1 /\left[\sigma^{2}\left(F_{0}^{2}\right)+0.2000 P\right)^{2}+0.0000 P\right]$ \\
\hline Largest diff. peak and hole & 0.13 and $-0.17 e \AA^{-3}$ & 0.17 and $-0.15 e \AA^{-3}$ \\
\hline
\end{tabular}

${ }^{\mathrm{a}} R=\left(\sum\left[\left(\left|F_{o}\right|-\left|F_{c}\right|\right) /\left(\sum\left|F_{o}\right|\right]\right) ;{ }^{\mathrm{b}} w R_{2}=\left\{\left[\sum\left(w\left[\left(F_{o}{ }^{2}-F_{c}{ }^{2}\right)^{2}\right] /\left[\sum\left(w\left(F_{o}{ }^{2}\right)^{2}\right)\right]\right\}^{1 / 2}\right.\right.\right.$.

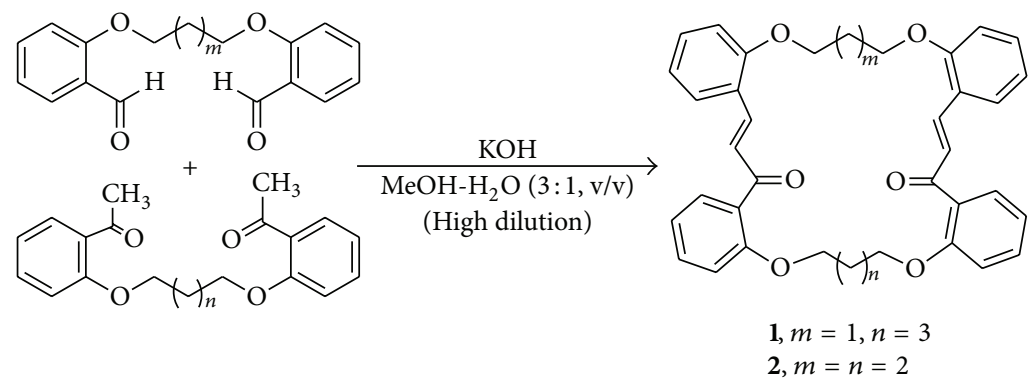

SCHEme 1: Synthesis of $\mathbf{1}$ and 2.

2.2. Single Crystal X-Ray Crystallography. A summary of the crystallographic data and conditions is given in Table 1. The selected bond lengths and bond angles of $\mathbf{1}$ and $\mathbf{2}$ are listed in Table 2. The structures of $\mathbf{1}$ and $\mathbf{2}$ as well as the packing arrangement in a unit cell of these compounds are shown in Figures 1 and 2, respectively. X-ray single crystal data collection and cell refinement were carried out at room temperature using a "Bruker SMART CCD-detector" diffractometer equipped with a normal focus, sealed tube $\mathrm{X}$-ray source with graphite monochromated Mo-K $\alpha$ radiation $(\lambda=$ $0.71073 \AA$ ). The structures were solved by direct methods and refined by full-matrix least-squares based $F^{2}$ using SHELXS 97 set of programs [19]. ORTEP-3 for Windows [20] and PLATON [21] programs were used for molecular graphics. The structures were drawn with Mercury for Windows [22].

\section{Results and Discussion}

The molecular structures of $\mathbf{1}$ and $\mathbf{2}$ are shown in Figure 1. Hydrogen bonding in the molecules is summarized in Table 2. For compound 1, the distances C15-C16 (1.458(3) $\AA$ ),

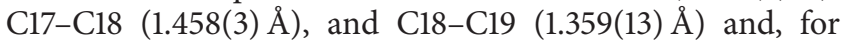


TABLE 2: Selected bond lengths $(\AA)$ and bond angles $\left({ }^{\circ}\right)$ of $\mathbf{1}$ and $\mathbf{2}$.

\begin{tabular}{lccr}
\hline \multicolumn{2}{c}{ Selected bond lengths for 1 } & \multicolumn{2}{c}{ Selected bond lengths for $\mathbf{2}$} \\
\hline $\mathrm{C}(15)-\mathrm{C}(16)$ & $1.458(3)$ & $\mathrm{C}(16)-\mathrm{C}(17)$ & $1.424(6)$ \\
$\mathrm{C}(16)-\mathrm{C}(17)$ & $1.324(3)$ & $\mathrm{C}(17)-\mathrm{C}(18)$ & $1.378(6)$ \\
$\mathrm{C}(17)-\mathrm{C}(18)$ & $1.458(3)$ & $\mathrm{C}(18)-\mathrm{C}(19)$ & $1.438(7)$ \\
$\mathrm{C}(18)-\mathrm{C}(19)$ & $1.359(3)$ & $\mathrm{C}(11)-\mathrm{O}(2)$ & $1.343(5)$ \\
$\mathrm{O}(1)-\mathrm{C}(1)$ & $1.359(13)$ & $\mathrm{C}(10)-\mathrm{O}(2)$ & $1.425(5)$ \\
$\mathrm{O}(1)-\mathrm{C}(7)$ & $1.426(11)$ & $\mathrm{C}(19)-\mathrm{O}(3)$ & $1.263(4)$ \\
\hline \multicolumn{2}{c}{ Selected bond angles for 1 } & & Selected bond angles for 2 \\
\hline $\mathrm{C}(6)-\mathrm{C}(38)-\mathrm{C}(37)$ & $127.07(19)$ & $\mathrm{C}(1)-\mathrm{C}(38)-\mathrm{C}(37)$ & $130.30(4)$ \\
$\mathrm{C}(15)-\mathrm{C}(16)-\mathrm{C}(17)$ & $\mathrm{C}(36)-\mathrm{C}(37)-\mathrm{C}(38)$ & $127.00(4)$ \\
$\mathrm{C}(17)-\mathrm{C}(18)-\mathrm{C}(17)$ & $\mathrm{C}(16)-\mathrm{C}(17)-\mathrm{C}(18)$ & $127.31(5)$ \\
$\mathrm{C}(35)-\mathrm{C}(36)-\mathrm{C}(37)$ & $\mathrm{C}(17)-\mathrm{C}(18)-\mathrm{C}(19)$ & $123.50(5)$ \\
$\mathrm{C}(7)-\mathrm{C}(8)-\mathrm{C}(9)$ & $\mathrm{C}(7)-\mathrm{C}(8)-\mathrm{C}(9)$ & $114.80(4)$ \\
$\mathrm{C}(25)-\mathrm{C}(26)-\mathrm{C}(27)$ & $\mathrm{C}(8)-\mathrm{C}(9)-\mathrm{C}(10)$ & $113.30(4)$ \\
$\mathrm{C}(26)-\mathrm{C}(27)-\mathrm{C}(28)$ & $\mathrm{C}(26)-\mathrm{C}(27)-\mathrm{C}(28)$ & $116.00(4)$ \\
$\mathrm{C}(27)-\mathrm{C}(28)-\mathrm{C}(29)$ & $\mathrm{C}(27)-\mathrm{C}(28)-\mathrm{C}(29)$ & $113.10(4)$ \\
$\mathrm{C}(29)-\mathrm{O}(5)-\mathrm{C}(30)$ & $\mathrm{C}(6)-\mathrm{O}(1)-\mathrm{C}(7)$ & $121.32(4)$ \\
$\mathrm{C}(24)-\mathrm{O}(4)-\mathrm{C}(25)$ & $119.03(15)$ & $\mathrm{C}(10)-\mathrm{O}(2)-\mathrm{C}(11)$ & $122.42(4)$ \\
$\mathrm{C}(9)-\mathrm{O}(2)-\mathrm{C}(10)$ & $122.38(15)$ & $\mathrm{C}(30)-\mathrm{O}(5)-\mathrm{C}(29)$ & $120.05(3)$ \\
$\mathrm{C}(1)-\mathrm{O}(1)-\mathrm{C}(7)$ & $114.60(19)$ & $\mathrm{C}(25)-\mathrm{O}(4)-\mathrm{C}(26)$ & $118.66(6)$ \\
\hline
\end{tabular}
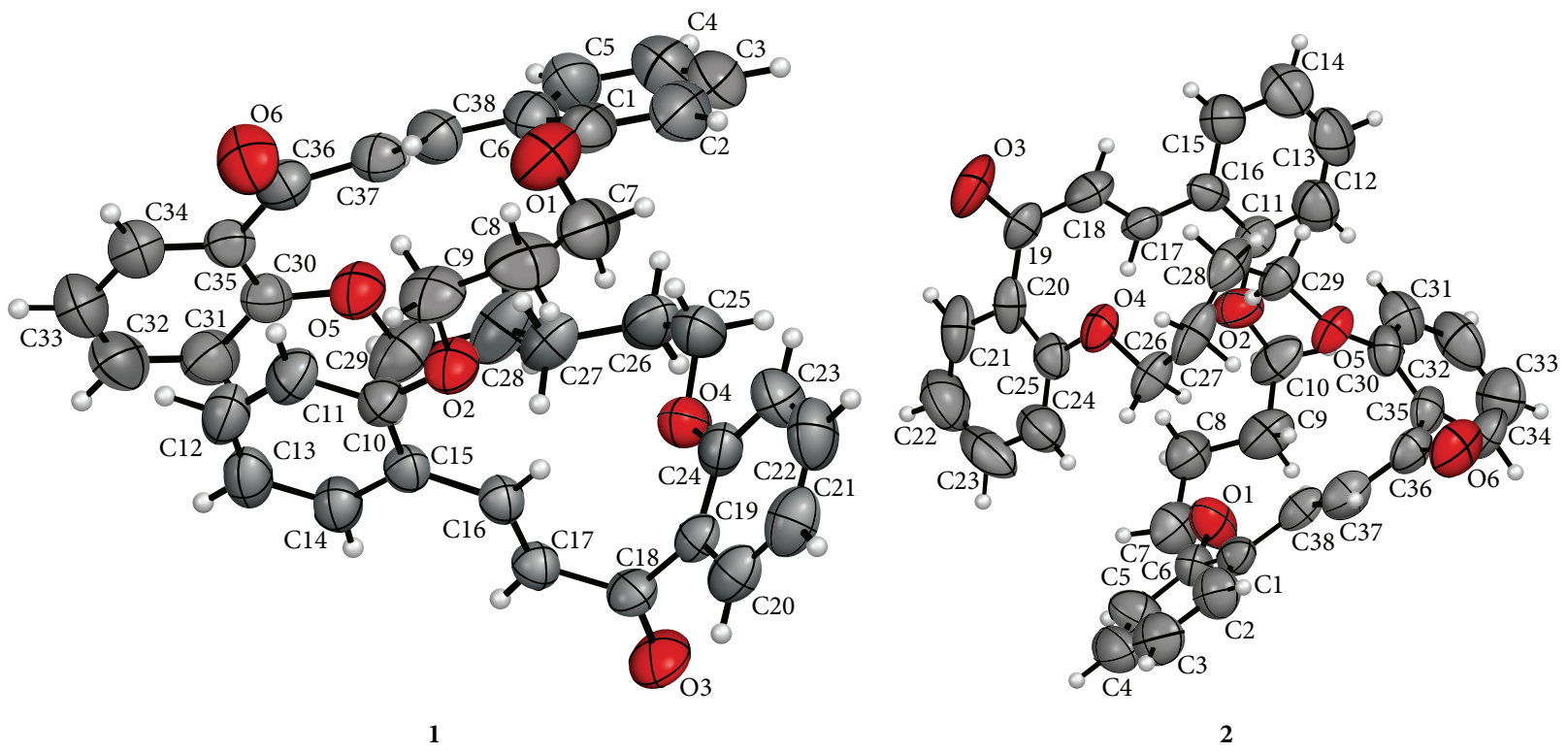

FIGURE 1: Molecular structure and atom numbering of compounds 1 and 2. (Displacement ellipsoids are drawn at the 50\% probability level.)

compound 2, the distances C16-C17 (1.424(6) $\AA$ ), C18-C19 (1.438(7) $\AA$ ), and C19-C20 (1.484(7) $\AA$ ) are shorter than the normal $\mathrm{C}-\mathrm{C}$ single bond $(1.53 \AA)$. However, the $\mathrm{C} 16-\mathrm{C} 17$ (1.324(3) $\AA$ ) distance for compound $\mathbf{1}$ is a bit shorter while C17-C18 (1.378(6) $\AA$ ) distance for compound 2 is somewhat longer than the normal C-C double bond (1.34 $\AA$ ). Again, in the case of compound $\mathbf{1}$, the $\mathrm{C} 18-\mathrm{C} 19$ bond length is very close to that of a C-C single bond. In both $\mathbf{1}$ and $\mathbf{2}$ each of the two phenyl rings attached to the $>\mathrm{C}=\mathrm{O}$ is not coplanar with the $\alpha, \beta$-unsaturated carbonyl moiety. All these may be due to accommodation of the polymethylene linkers in the molecules.

In case of compound $\mathbf{1}$, for the first chalcone moiety, the $\alpha, \beta$-unsaturated carbonyl unit $(\mathrm{C} 16-\mathrm{C} 17-\mathrm{C} 18)$ is almost coplanar with the phenyl ring $\mathrm{C} 10-\mathrm{C} 11-\mathrm{C} 12-\mathrm{C} 13-$ C14-C15 (angle $3.69(5)^{\circ}$ ) but is not so with the phenyl ring C19-C20-C21-C22-C23-C24 (angle 69.69 $(12)^{\circ}$ ), while, for the second chalcone moiety, the $\alpha, \beta$-unsaturated carbonyl unit (C36-C37-C38) is not coplanar with any of the two phenyl rings $\mathrm{C} 30-\mathrm{C} 31-\mathrm{C} 32-\mathrm{C} 33-\mathrm{C} 34-\mathrm{C} 35$ and 
TABLE 3: Intermolecular hydrogen bonds, intramolecular $\mathrm{C}-\mathrm{H} \cdots \mathrm{O}$, and $\mathrm{C}-\mathrm{H} \cdots \pi$ supramolecular interactions in $\mathbf{1}$ and 2.

\begin{tabular}{|c|c|c|c|c|c|c|}
\hline & $\mathrm{D}-\mathrm{H} \cdots \mathrm{A}$ & Symmetry & $\begin{array}{c}\text { D-H } \\
(\AA)\end{array}$ & $\begin{array}{c}\mathrm{H} \cdots \mathrm{A} \\
(\AA)\end{array}$ & $\begin{array}{c}\mathrm{D} \cdots \mathrm{A} \\
(\AA)\end{array}$ & $\begin{array}{c}\mathrm{D}-\mathrm{H} \cdots \mathrm{A} \\
(\AA)\end{array}$ \\
\hline \multirow{7}{*}{ Compound 1} & $\mathrm{C} 8-\mathrm{H} 8 \mathrm{~B} \cdots \mathrm{O} 2$ & $3 / 2-x, 1 / 2-y, 1-z$ & 0.9700 & 2.5400 & $3.469(3)$ & 162 \\
\hline & $\mathrm{C} 14-\mathrm{H} 14 \cdots \mathrm{O} 6$ & $x, 1-y,-1 / 2+z$ & 0.9300 & 2.6000 & $3.411(2)$ & 146 \\
\hline & $\mathrm{C} 16-\mathrm{H} 16 \cdots \mathrm{O} 2$ & - & $0.931(15)$ & $2.295(15)$ & $2.717(2)$ & 107 \\
\hline & C29-H29B ‥ O6 & $x, 1-y, 1 / 2+z$ & 0.9700 & 2.4500 & $3.382(2)$ & 161 \\
\hline & $\mathrm{C} 37-\mathrm{H} 37 \cdots \mathrm{O} 5$ & - & $0.970(17)$ & $2.243(17)$ & $2.726(2)$ & 109 \\
\hline & $\mathrm{C} 38-\mathrm{H} 38 \cdots \mathrm{O} 1$ & - & $1.01(2)$ & $2.323(19)$ & $2.717(3)$ & 101 \\
\hline & C7-H7B $\cdots$ phenyl ring & $x,-y,-1 / 2+z$ & 0.9700 & 2.8500 & $3.708(2)$ & 148 \\
\hline \multirow{5}{*}{ Compound 2} & $\mathrm{C} 8-\mathrm{H} 8 \mathrm{~B} \cdots \mathrm{O} 2$ & - & 0.9700 & 2.4800 & $2.852(11)$ & 103 \\
\hline & C9-H9B $\cdots$ O1 & - & 0.9700 & 2.4100 & $2.809(10)$ & 104 \\
\hline & $\mathrm{C} 21-\mathrm{H} 21 \cdots \mathrm{O} 3$ & $-x, 2-y, 1-z$ & 0.9300 & 2.5100 & $3.407(13)$ & 161 \\
\hline & $\mathrm{C} 34-\mathrm{H} 34 \cdots \mathrm{O} 6$ & $1-x,-y,-z$ & 0.9300 & 2.4700 & $3.371(13)$ & 164 \\
\hline & $\mathrm{C} 14-\mathrm{H} 14 \cdots$ phenyl ring & $1-x,-y, 1-z$ & 0.9300 & 2.8200 & 3.735 & 167 \\
\hline
\end{tabular}
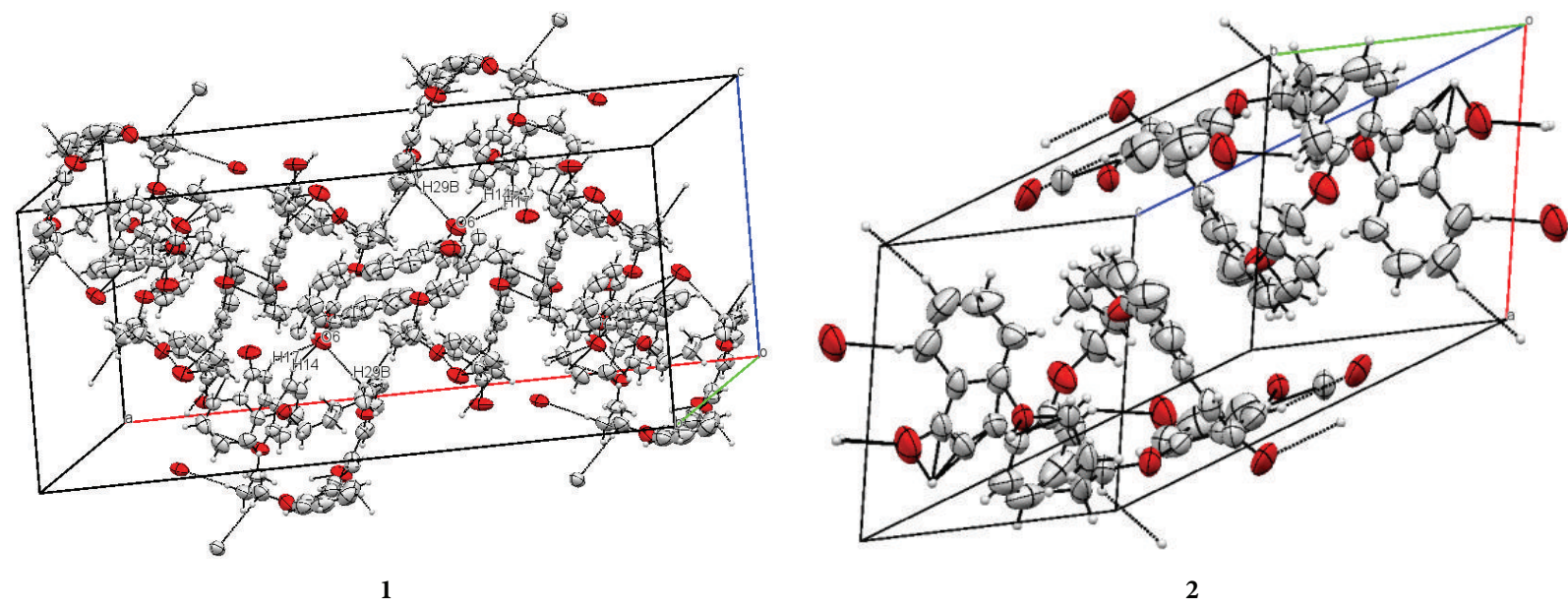

FIGURE 2: The packing arrangement in the unit cells of $\mathbf{1}$ and $\mathbf{2 .}$

C1-C2-C3-C4-C5-C6 (angles 16.82(9) and 22.90(11) ${ }^{\circ}$, resp.). On the other hand, in compound 2 , arrangement is the same in both chalcone moieties. In each case the $\alpha, \beta$ unsaturated carbonyl unit is almost coplanar with one phenyl ring $\mathrm{C} 1-\mathrm{C} 2-\mathrm{C} 3-\mathrm{C} 4-\mathrm{C} 5-\mathrm{C} 6$ or $\mathrm{C} 11-\mathrm{C} 12-\mathrm{C} 13-\mathrm{C} 14-\mathrm{C} 15-\mathrm{C} 16$ (angle $1.20(3)$ or $3.33(4)^{\circ}$ ) while it makes an angle of nearly $67^{\circ}$ with the other phenyl rings C30-C31-C32-C33-C34C35 or C20-C21-C22-C23-C24-C25. It is therefore apparent that the extent of electron delocalization between the phenyl ring attached to carbonyl and the remaining part of the chalcone moiety is very poor for both compounds 1 and 2. The aliphatic chains $\mathrm{O} 1-\mathrm{C} 7-\mathrm{C} 8-\mathrm{C} 9-\mathrm{O} 2$ and $\mathrm{O} 4-\mathrm{C} 25-$ C26-C27-C28-C29-O5 in $\mathbf{1}$ and O1-C7-C8-C9-C10-O2 and $\mathrm{O} 4-\mathrm{C} 26-\mathrm{C} 27-\mathrm{C} 28-\mathrm{C} 29-\mathrm{O} 5$ in 2 are mostly in staggered arrangement with the dihedral angles ranging from 57 to $64^{\circ}$. Antiarrangements were observed for C25-C26-C27C28 and C26-C27-C28-C29 in $\mathbf{1}$ and C7-C8-C9-C10 in 2 (dihedral angles 177.32(17), 176.19(17), and 175.10(9) ${ }^{\circ}$, resp.). It is interesting to note that the arrangements for the apparently similar units C7-C8-C9-C10 and C26-C27-C28-C29 in 2 are somewhat different in the crystalline state. For the first unit it is anti while for the second unit it is staggered. In the unit cell containing two molecules of $\mathbf{2}$ (Figure 2), two anti units are much closer than two staggered ones.

The salient feature of the crystal packing of $\mathbf{1}$ and $\mathbf{2}$ is that both of them form intermolecular hydrogen bonding networks (Figure 2). For the crystal of each compound there are two types of $\mathrm{C}-\mathrm{H} \cdots \mathrm{O}$ intermolecular hydrogen bonds and one type of $\mathrm{C}-\mathrm{H} \cdots \pi$ supramolecular interactions (Table 3 ). In the crystal lattices, all the abovementioned hydrogen bonds and intermolecular interactions play a significant role in stabilizing the crystal structures. The intermolecular hydrogen bonds in $\mathbf{1}$ and $\mathbf{2}$ are summarized in Table 3.

Supplementary full crystallographic information for compounds 1 (CCDC 999278) and 2 (CCDC 999279) can be obtained via http://www.ccdc.cam.ac.uk/conts/retrieving .html or from the Cambridge Crystallographic Data Centre, 12 Union Road, Cambridge, UK. 


\section{Conclusions}

Several interesting structural aspects of two macrocyclic bischalcones $\mathbf{1}$ and 2 , each containing a 26-membered ring, in the solid state were evident from their single crystal X-ray diffraction studies.

\section{Conflict of Interests}

The authors declare that there is no conflict of interests regarding the publication of this paper.

\section{Acknowledgments}

Financial assistance from the UGC-CAS and DST-PURSE programs and instrumental facilities from the DST-FIST program, Department of Chemistry, Jadavpur University, are gratefully acknowledged. Rina Mondal and Nayim Sepay are thankful to the UGC, New Delhi, for the award of research fellowships.

\section{References}

[1] D. N. Dhar, The Chemistry of Chalcones and Related Compounds, Wiley, New York, NY, USA, 1981.

[2] A. Solankee, S. Lad, S. Solankee, and G. Patel, "Chalcones, pyrazolines and aminopyrimidines as antibacterial agents," Indian Journal of Chemistry, Section B: Organic and Medicinal Chemistry, vol. 48, no. 10, pp. 1442-1446, 2009.

[3] J. C. Trivedi, J. B. Bariwal, K. D. Upadhyay et al., "Improved and rapid synthesis of new coumarinyl chalcone derivatives and their antiviral activity," Tetrahedron Letters, vol. 48, no. 48, pp. 8472-8474, 2007.

[4] B. P. Bandgar, S. A. Patil, B. L. Korbad, S. H. Nile, and C. N. Khobragade, "Synthesis and biological evaluation of $\beta$-chloro vinyl chalcones as inhibitors of TNF- $\alpha$ and IL- 6 with antimicrobial activity," European Journal of Medicinal Chemistry, vol. 45, no. 6, pp. 2629-2633, 2010.

[5] B. C. Das, G. Marappan, S. Saha, D. Bhowmik, and Chiranjib, "Anthelmintic and anti-microbial activity of some novel chalcone derivatives," Journal of Chemical and Pharmaceutical Research, vol. 2, no. 1, pp. 113-120, 2010.

[6] R. Li, G. L. Kenyon, F. E. Cohen et al., "In vitro antimalarial activity of chalcones and their derivatives," Journal of Medicinal Chemistry, vol. 38, no. 26, pp. 5031-5037, 1995.

[7] X. Wu, E. R. T. Tiekink, I. Kostetski et al., "Antiplasmodial activity of ferrocenyl chalcones: investigations into the role of ferrocene," European Journal of Pharmaceutical Sciences, vol. 27, no. 2-3, pp. 175-187, 2006.

[8] Y. Xia, Z.-Y. Yang, P. Xia, K. F. Bastow, Y. Nakanishi, and K.H. Lee, "Antitumor agents. Part 202: novel 2' -amino chalcones: design, synthesis and biological evaluation," Bioorganic and Medicinal Chemistry Letters, vol. 10, no. 8, pp. 699-701, 2000.

[9] A. R. Trivedi, D. K. Dodiya, N. R. Ravat, and V. H. Shah, "Synthesis and biological evaluation of some new pyrimidines via a novel chalcone series," Arkivoc, vol. 2008, no. 11, pp. 131-141, 2008.

[10] A. Voskiene and V. Mickevičius, "Cyclization of chalcones to isoxazole and pyrazole derivatives," Chemistry of Heterocyclic Compounds, vol. 45, no. 12, pp. 1485-1488, 2009.
[11] K. Bahrami, M. M. Khodaei, F. Naali, and B. H. Yousefi, "Synthesis of polysubstituted pyridines via reactions of chalcones and malononitrile in alcohols using Amberlite IRA-400 ( $\left.\mathrm{OH}^{-}\right)$," Tetrahedron Letters, vol. 54, no. 39, pp. 5293-5298, 2013.

[12] F. Vögtle, Supramolecular Chemistry, John Wiley \& Sons, Chichester, UK, 1991.

[13] J. P. Sauvage, Ed., Molecular Machines and Motors, Springer, Berlin, Germany, 2001.

[14] J. M. Lehn, Supramolecular Chemistry: Concepts and Perspectives, $\mathrm{VCH}$, Weinheim, Germany, 1995.

[15] D. J. Cram and J. M. Cram, Container Molecules and Their Guests, Royal Society of Chemistry, Cambridge, UK, 1994.

[16] R. Matsushima, S. Fujimoto, and K. Tokumura, "Dual photochromic properties of 4-dialkylamino-2-hydroxychalcones," Bulletin of the Chemical Society of Japan, vol. 74, no. 5, pp. 827832, 2001.

[17] K. Rurack, M. L. Dekhtyar, J. L. Bricks, U. Resch-Genger, and W. Rettig, "Quantum yield switching of fluorescence by selectively bridging single and double bonds in chalcones: involvement of two different types of conical intersections," Journal of Physical Chemistry A, vol. 103, no. 48, pp. 9626-9635, 1999.

[18] R. Mondal, T. K. Mandal, and A. K. Mallik, "Simple synthesis of a new family of 22- to 28-membered macrocycles containing two chalcone moieties," Arkivoc, vol. 2012, no. 9, pp. 95-110, 2012.

[19] G. M. Sheldrick, "A short history of SHELX”, Acta Crystallographica A, vol. 64, no. 1, pp. 112-122, 2008.

[20] L. J. Farrugia, "ORTEP-3 for windows-a version of ORTEPIII with a graphical user interface (GUI)," Journal of Applied Crystallography, vol. 45, no. 4, pp. 849-855, 2012.

[21] A. L. Spek, "Structure validation in chemical crystallography," Acta Crystallographica Section D: Biological Crystallography, vol. 65, no. 2, pp. 148-155, 2009.

[22] C. F. Macrae, P. R. Edgington, P. McCabe et al., "Mercury: visualization and analysis of crystal structures," Journal of Applied Crystallography, vol. 39, part 3, pp. 453-457, 2006. 

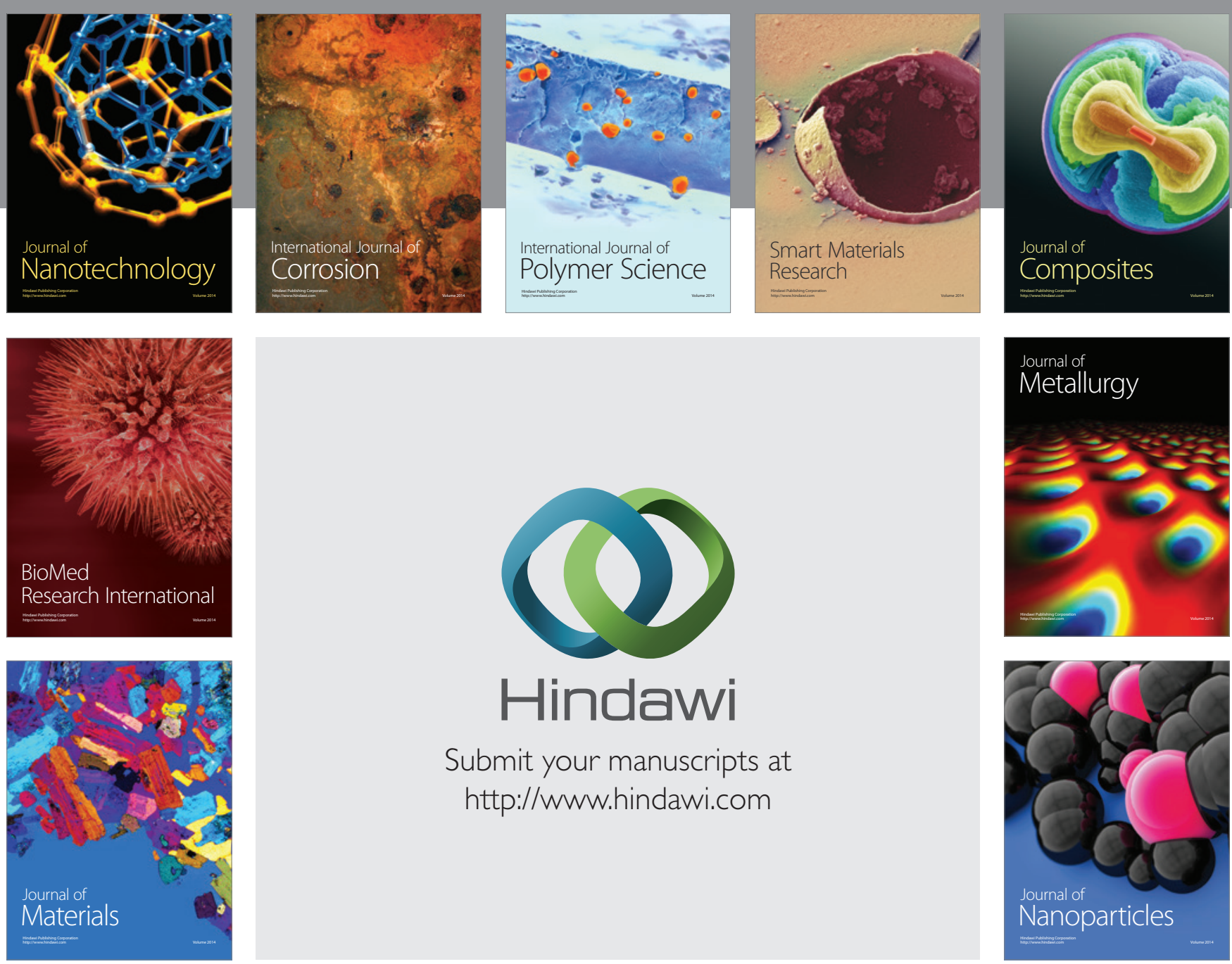

Submit your manuscripts at http://www.hindawi.com
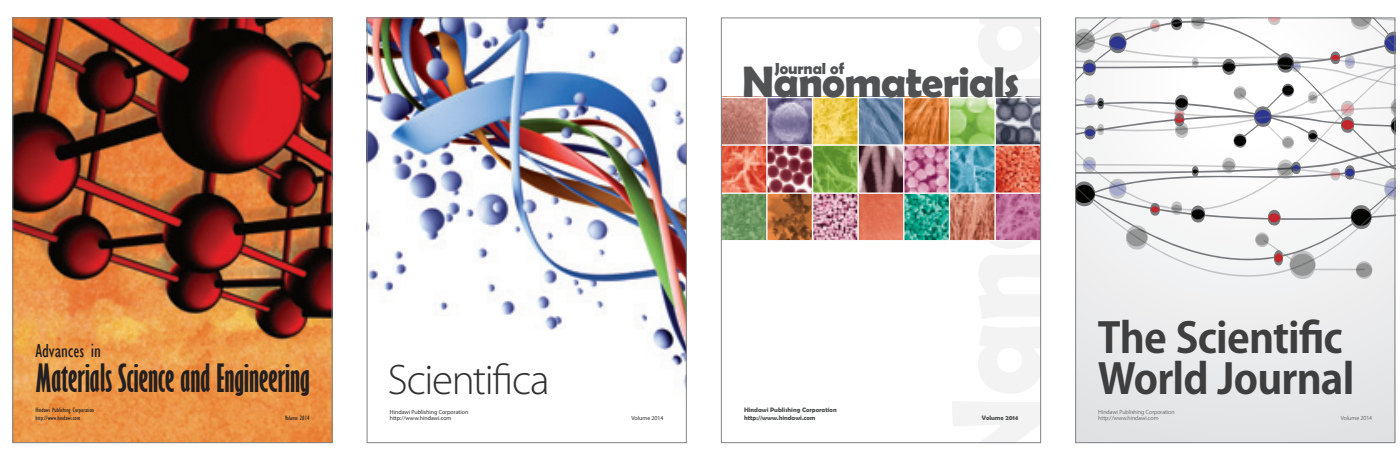

\section{The Scientific World Journal}
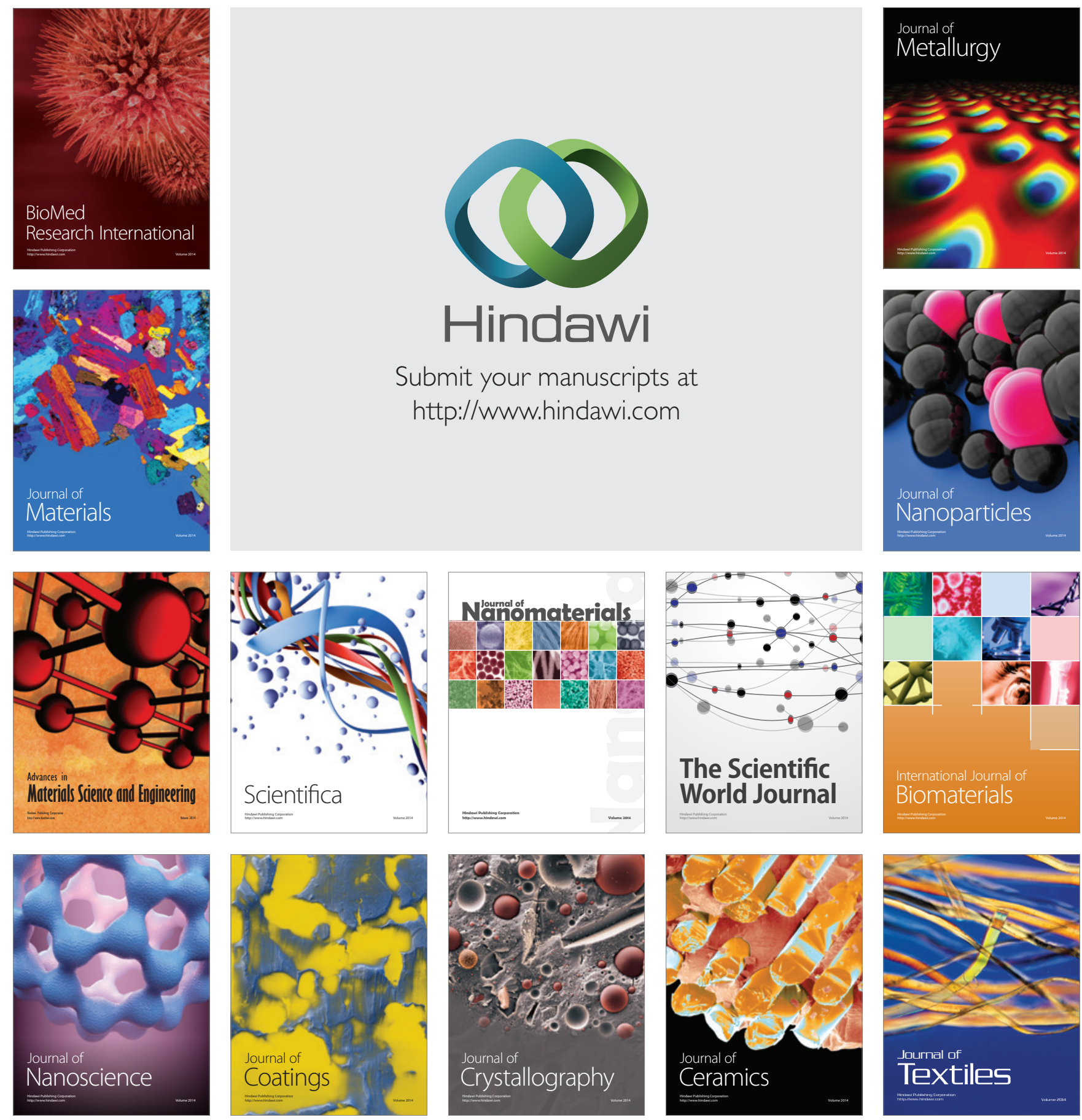